\title{
ANTIOXIDANT AND ANTI-CYTOLYTIC ACTIVITY OF PARSNIP (Pastinaca sativa L.) HERB THICK EXTRACT IN CONDITIONS OF CATECHOLAMINE MYOCARDIODYSTROPHY IN RATS
}

\author{
Natalia Symonenko, Oleh Shpychak, Oksana Mishchenko, Viktoriia Kyslychenko, \\ Tamara Shpychak, Svetlana Graschenkova
}

\begin{abstract}
The aim: to study the antioxidant and anticytolytic activity of the parsnip herb thick extract (PHTE) in conditions of catecholamine myocardial dystrophy in rats.

Materials and methods. Catecholamine myocardial dystrophy was reproduced in rats by a single subcutaneous injection of $0.18 \%$ adrenaline hydrochloride solution at a dose of $0.5 \mathrm{mg} / \mathrm{kg}(0.28 \mathrm{ml} / \mathrm{kg})$ of body weight. The experiment used 36 white male rats with an initial weight of 220-250 g, 4-4.5 months of age. The tested drugs were PHTE at doses of 100 and $200 \mathrm{mg} / \mathrm{kg}$ and the reference drug (RD) "Tricardin" were administered intragastrically in a therapeutic and prophylactic regimen for 7 days, the last time on the day of the experiment 1 hour before the administration of cardiotoxin. The activity of the studied agents was assessed by the survival rate of the animals, the functional state of the myocardium (ECG studies), by the effect on the heart mass ratio (HMR), the activity of aspartate aminotransferase (ASAT), the level of active products interacting with thiobarbituric acid (TBA-AP) and the content of reduced glutathione (RG) in the heart homogenate.

Results. The study of the effect of PHTE on the lipid peroxidation / antioxidant protection (LPO / AOP) system showed that a pronounced antioxidant effect of the tool was found at a dose of $200 \mathrm{mg} / \mathrm{kg}$ : there was an increase in VG at the trend level $(0.05<p<0.10)$ and a significant decrease $(p<0.05)$ the content of TBK-AP in 1.85 times compared with the group of positive control (PC). A similar effect was found in the comparison drug "Tricardin". PHTE at a dose of $100 \mathrm{mg} / \mathrm{kg}$ was less influential. The use of PHTE in both doses and the comparison drug "Tricardin" reduced the severity of cytolytic processes: the activity of the enzyme AST - a marker of cardiocytolysis, was lower than in the PC group. $P H T E$ at doses of 100 and $200 \mathrm{mg} / \mathrm{kg}$ contributed to a certain normalization of some ECG parameters compared to PC: a slight insignificant decrease in heart rate and a significant decrease ( $p<0.05)$, QT interval, systolic index (SI) and decreased ischemia marker - ST segment displacement. The comparison drug "Tricardin" showed a similar effect to PHTE on the functional state of the myocardium in adrenaline intoxication.

Conclusions. Parsnip herb thick extract exhibits antioxidant and anticytolytic activity, improves the functional state of the myocardium, prevents a decrease in the severity of alterative processes in the organ under conditions of adrenaline myocardial dystrophy
\end{abstract}

Keywords: catecholamine (adrenal) myocardial dystrophy, parsnip herb thick extract (PHTE), antioxidant and anticytolytic activity

How to cite:

Symonenko, N., Shpychak, O., Mishchenko, O., Kyslychenko, V., Shpychak, T., Graschenkova, S. (2022). Antioxidant and anti-cytolytic activity of parsnip (Pastinaca sativa L.) herb thick extract in conditions of catecholamine myocardiodystrophy in rats. ScienceRise: Pharmaceutical Science, 1 (35), 70-76. doi: http://doi.org/10.15587/1729-4061.2022.253546

(C) The Author(s) 2022

This is an open access article under the Creative Commons CC BY license hydrate

\section{Introduction}

Cardiovascular diseases occupy a leading position in terms of mortality among other diseases. In the genesis of their development, an important place is given to stress as a risk factor, the initiation of which involves the pathogenic effects of catecholamines, namely adrenaline $[1,2]$. Adrenaline has both a direct negative effect on the myocardium and mediated by significant metabolic disorders, which leads to irreversible damage to cardiomyocytes [3, 4]. Superphysiological levels of catecholamines in blood plasma, above all, contributes to the violation of myocardial lipid homeostasis and causes disruption of lipid metabolism in the heart, which in turn enhances lipotoxicity and lipid peroxidation (LPO) [5]. Against the background of LPO intensification in the myocardium, cytolytic processes are also intensified, which leads to cardiac dysfunction. Determinant under such conditions is the state of the antioxidant system that counteracts the processes of LPO [6, 7].

Given the above, the use of antioxidants, in particular plant phenolic compounds, which inhibit the formation of free radicals and increase the activity of antioxidant protection $[7,8]$ in catecholamine myocardiopathy, is appropriate. Promising in this regard are prepara- 
tions obtained from plant raw materials of parsnip (Pastinaca sativa L.). Recent studies have shown that biologically active substances (including furocoumarins - remove) parsnips have the ability to dilate peripheral vessels and coronary vessels of the heart, eliminate spasms of the bronchi and smooth muscles of the abdominal cavity, have a moderate sedative effect $[9,10]$. However, the antioxidant properties of biologically active substances of parsnip have been insufficiently covered in the scientific literature, in particular in catecholamine cardiomyodystrophy.

The aim of the work - study of antioxidant and anticytolytic activity of parsnip herb thick extract (PHTE) in catecholamine myocardial infarction in rats.

\section{Planning (methodology) of research}

Catecholamine myocardial infarction in rats is a well-reproduced model of myocardial damage, similar to that in patients with stress-induced myocardiopathy, which is a very common cardiovascular disease $[1,2]$. Given this, the study used this experimental model using the basic principles of the concept of Quality by design [11].

\section{Materials and methods}

The tests were conducted in the autumn of 2021 . White laboratory rats obtained from the vivarium of the Educational and Scientific Institute of Applied Pharmacy of the National University of Pharmacy, Kharkiv were selected for the study. Animals were kept in a room with controlled microclimate parameters: air temperature $+18-22{ }^{\circ} \mathrm{C}$, relative humidity $50-65 \%$, light regime " 12 hours day / night" in accordance with the rules of laboratory animals [12]. Animals were treated in accordance with the rules of the "European Convention for the Protection of Vertebrate Animals Used for Experimental and Scientific Purposes" [13]. The draft research plan was approved by the NUPh Bioethics Commission (Minutes No. 6 of 08.06.2021). The study was conducted in accordance with the guidelines [14], in compliance with the requirements of Good Laboratory Practice [15].

The experiment used 36 white male rats with an initial weight of 220-250 g, aged 4-4.5 months. Animals were divided into 4 groups: group 1 - intact control (IC); group 2 - positive control (PC); group 3 - animals receiving PHTE at a dose of $100 \mathrm{mg} / \mathrm{kg}$; group 4 - animals receiving PHTE at a dose of $200 \mathrm{mg} / \mathrm{kg}$; group 5 - animals that received the comparison drug (CD) "Tricardin" [16] (1 $\mathrm{ml}$ of drops contains: valerian tincture (tinctura Valerianae) (1: 5) (extractant ethanol $70 \%)-0.34 \mathrm{ml}$, hawthorn tincture (tinctura Crataegi) (1:10) (extractant ethanol $70 \%)-0.33 \mathrm{ml}$, nettle (motherwort) tincture (tinctura Leonuri) (1: 5) (extractant ethanol $70 \%$ ) - 0.33 ml, produced by LLC "Ternopharm", Ukraine) at a dose of 5 drops $/ \mathrm{kg}$ body weight (calculated on the total weight of animals, the number of drops of the drug was diluted with distilled water to a volume of $1 \mathrm{ml} / 1 \mathrm{~kg}$, then injected the resulting liquid at a rate of $0.1 \mathrm{ml} / 100 \mathrm{~g}$ body weight animals). The drug "Tricardin" was used in the dose determined by transferring from the daily dose for humans to rats using the method of Ulanova I. P. [17]. The drug "Tricardin" was chosen as a comparative drug as an analogue in pharmacological action and origin.
Parsnip herb thick extract (PHTE) was obtained by scientists of NUPh in the phytochemical laboratory under the direction of the head of the Department of Chemistry of Natural Compounds and Nutrition, Doctor of Pharmacy, prof. Kislichenko V. S.

Previous pharmacognostic analysis showed that the resulting thick extract contains phenolic compounds, including coumarins, flavonoids, hydroxycinnamic acids, as well as polysaccharides, amino acids, volatile compounds, organic acids and other biologically active substances $[18,19]$.

The extract is produced from the terrestrial part of Pastinaca sativa L. by triple fractional maceration from crushed raw materials using $70 \%$ ethanol extractant at a raw material-extractant ratio (1:5) followed by evaporation under vacuum [18]. A "Specification" for the obtained thick extract was developed according to the following indicators: production, description, identification (phenolic compounds), weight loss during drying, quantification of polyphenolic compounds in terms of gallic acid, storage and shelf life included in the "Methods of quality control" for the obtained substance $[18,19]$.

In addition, we have added the following quality indicators to the updated part of the "Specification" and "Quality Control Methods" (QCM) on "Parsnip herb thick extract", set out in version II: solubility, total ash, heavy metals and microbiological purity

In accordance with the requirements of the developed QCM on parsnip herb thick extract (Pastinacae sativae herbae extractum spissum) plant substance is a viscous mass of brown color with a fragrant odor, which is easily soluble in water, soluble in ethanol, practically insoluble in glycerol plants and mineral and insoluble in chloroform and ethyl acetate.

Identification of phenolic compounds was performed by TLC. As the mobile phase was used: ethyl acetate P-acetic acid P-formic acid P-water P (100:11:11:25). Hyperoside was identified in the PHTE by the presence of a comparison solution of the fluorescent yellow-brown zone in PHTE, and chlorogenic acid by the presence of a blue fluorescent zone [19].

The weight loss during drying in the studied samples of the thick extract is $22.0 \%$; total ash $-7.8 \%$; heavy metal content $-0.001 \%(1000 \mathrm{ppm})$, which corresponds to the established standards specified in the developed regulations. The substance also passes the test for microbiological purity. The total number of aerobic microorganisms (TAMC) is not more than $10^{4} \mathrm{CFU} / \mathrm{g}$. The total number of yeasts and molds (TYMC) is not more than $10^{2} \mathrm{CFU} / \mathrm{g}$. No more than $10^{2}$ tolerant to bile gram-negative bacteria in $1.0 \mathrm{~g}$. Absence of Salmonella in $25.0 \mathrm{~g}$. Absence of E. coli in $1.0 \mathrm{~g}$.

According to the results obtained on the study of solubility in the obtained samples of PHTE (Table 1) and determination of dry residue and $\mathrm{pH}$ level (Table 2), it should be concluded that PHTE has a pronounced hydrophilic nature: practically insoluble in hexane, petroleum ether, chloroform, mineral and vegetable oils, ethanol; easily soluble in purified water, water-alcohol mixtures (40-70 \% alcohol), glycerin, propylene glycols, PEO-400. 
The results of the study of the solubility of experimental samples of PHTE

\begin{tabular}{|c|c|c|}
\hline No. & The name of the solvent & PHTE solubility \\
\hline 1 & Hexane & Practically insoluble \\
\hline 2 & Chloroform & Practically insoluble \\
\hline 3 & Petroleum ether & Practically insolubleluble \\
\hline 4 & Glycerin & Practically insoluble \\
\hline 5 & Vaseline oil & Practically insoluble \\
\hline 6 & Vegetable oils & Easily soluble \\
\hline 7 & Purified water & Soluble \\
\hline 8 & Ethanol $96 \% \mathrm{v} / \mathrm{v}$ & Easily soluble \\
\hline 9 & Ethanol $70 \% \mathrm{v} / \mathrm{v}$ & Easily soluble \\
\hline 10 & Ethanol $40 \% \mathrm{v} / \mathrm{v}$ & Easily soluble \\
\hline 11 & Propylene glycol & Easily soluble \\
\hline 12 & PEO-400 & \\
\hline
\end{tabular}

According to the results of determining the dry residue in the plant substance PHTE (Table 2), it was found that this indicator ranges from 76 to $80 \%$, which meets the requirements of the general monograph "Extracts" SPhU [20].

The results of the study of the $\mathrm{pH}$ of the PHTE solution (Table 2) showed that the $\mathrm{pH}$ is in the range from 4.70 to 6.30 depending on the series of the drug. The content of heavy metals in the studied series of PHTE is less than $0.01 \%$, which also meets the requirements of $\mathrm{SPhU}$ [20]. According to the results of quantitative determination, the content of polyphenolic compounds in the studied PHTE samples is $10.5 \%$.

PHTE samples were used at doses of 100 and $200 \mathrm{mg} / \mathrm{kg}$, for which the ability to normalize heart rate in adrenaline was found in previous studies [21].

Dry residue content and $\mathrm{pH}$ level in experimental and industrial samples of plant substance PHTE

\begin{tabular}{|c|c|c|}
\hline No. PHTE sample & Dry residue, $\%$ & $\mathrm{pH}$ \\
\hline 011020 & $76.23 \pm 1.24$ & $5.70 \pm 0.08$ \\
\hline 021020 & $78.25 \pm 1.45$ & $6.20 \pm 0.02$ \\
\hline 031020 & $79.12 \pm 1.09$ & $6.30 \pm 0.04$ \\
\hline 041020 & $77.82 \pm 1.51$ & $4.70 \pm 0.01$ \\
\hline 051020 & $78.56 \pm 1.35$ & $5.90 \pm 0.05$ \\
\hline
\end{tabular}

The study drugs were administered intragastrically in the treatment-and-prophylactic mode for 7 days, the last time on the day of the experiment 1 hour before the introduction of cardiotoxin. Pathology was reproduced in all experimental rats except the intact control group. Adrenaline-induced pathology was initiated by a single subcutaneous injection of $0.18 \%$ solution of epinephrine hydrochloride at a dose of $0.5 \mathrm{mg} / \mathrm{kg}(0.28 \mathrm{ml} / \mathrm{kg})$ of body weight [22].

The effect on the myocardium of cardiotoxin and the studied drugs was evaluated by the survival of animals, the functional state of the myocardium (ECG study), the effect on the relative coefficient of body mass (BM) of the heart by the formula:

$$
\text { Heart } \mathrm{BM}=\left(\mathrm{m}_{\text {organ }}(\mathrm{g}) / \mathrm{M}_{\text {animal }}(\mathrm{g}) \times 100 \%\right.
$$

and biochemical parameters in blood serum and heart homogenate. After 24 hours of administration of epinephrine hydrochloride in animals under mild chloroform anesthesia, cardiovascular performance was recorded using an EC1T 03M electrocardiograph, after which they were removed from the experiment by euthanasia.

In the homogenate of the heart was determined by the activity of the marker enzyme cardiocytolysis - aspartate aminotransferase (AST) using the Lachema test kit (Czech Republic). The cardioprotective effect of the drugs was also evaluated by the effect on lipid peroxidation
(LPO) and antioxidant protection (AOP): the level of active products that interact with thiobarbituric acid (TBA) [23] and the content of reduced glutathione (RG) [24].

Performance indicators of the cardiovascular system were recorded using an electrocardiograph EK1T $03 \mathrm{M}$ in the II standard lead. The following indicators were taken into account when interpreting the electrocardiogram: R-R - duration of the complete cardiac cycle; the duration of the interval P-Q, which characterizes the atrioventricular conduction; duration of ventricular QRS complex and electrical ventricular systole - QT interval; voltage of teeth $\mathrm{P}, \mathrm{T}$ and $\mathrm{R}$. Calculated the following indicators: heart rate (heart rate, beats / $\mathrm{min}$ ) as the ratio of time $(60 \mathrm{~s})$ to the duration of the cardiac cycle RR and systolic index (SP) as the ratio of the duration of the QT interval to the duration of the cardiac cycle RR (QT/RR, \%) [14].

Experimental data were processed by methods of variation statistics (mean value and its standard error, $\mathrm{M} \pm \mathrm{m}$ ) using parametric (one-way analysis of variance ANOVA) and nonparametric methods of analysis (Kruskal-Wallis test). Accepted significance level $\mathrm{p}<0.05$. The standard STATISTICA software package (version 6) was used to obtain statistical conclusions.

\section{Results}

When modeling the pathology as a result of subcutaneous adrenaline, one rat from the PC group died, the 
survival rate of animals in this group was $86 \%$, which is consistent with the literature [25]. According to the data (Table 3), it could be argued that the surviving PC animals developed myocardial infarction, characterized by changes in many indicators of the cardiovascular system, determined by ECG 24 hours after the initiation of pathology.

The development of cytolytic processes in the myocardium of PC rats was accompanied by a significant increase in 1.62 times the level of the marker enzyme cytolysis AST in the serum relative to group IC (Table 3). Probable increase in heart rate indicates the development of myocardial infarction, accompanied by increased alternative processes, tissue damage, destruction of myocardial cells [26, 27]. An imbalance in the lipid peroxidation system / antioxidant protection (LPO/AOP) was observed in the myocardial tissues of PC animals, as evidenced by a significant $(\mathrm{p}<0.05)$ increase in TBA content by 1.8 times compared to IC. Statistically significant in comparison with the IC group 2.26-fold decrease in the level of RG in the heart tissue indicate the depletion of antioxidant protection in the case of adrenalineinduced pathology (Table 4).

Table 3

The effect of PHTE and the comparison drug "Tricardin" on the course of adrenaline myocardial infarction in rats (M $\pm \mathrm{m})$

\begin{tabular}{|c|c|c|c|c|c|}
\hline \multirow[b]{2}{*}{ Indicators } & \multicolumn{5}{|c|}{ Study conditions } \\
\hline & $\begin{array}{c}\text { Intact control } \\
(n=6)\end{array}$ & $\begin{array}{c}\text { Positive control } \\
(\mathrm{n}=5)\end{array}$ & $\begin{array}{c}\text { PHTE, } 100 \mathrm{mg} / \mathrm{kg} \\
(\mathrm{n}=6)\end{array}$ & $\begin{array}{c}\text { PHTE, } 200 \\
\mathrm{mg} / \mathrm{kg}(\mathrm{n}=6)\end{array}$ & $\begin{array}{c}\text { Tricardin, } 5 \\
\text { drops } / \mathrm{kg}(\mathrm{n}=6)\end{array}$ \\
\hline Survival, \% & 100 & 86 & 100 & 100 & 100 \\
\hline Heart MK, \% & $0.31 \pm 0.01$ & $0.37 \pm 0.01 *$ & $0.35 \pm 0.01 \mathrm{t}^{*}$ & $0.32 \pm 0.01 * *$ & $0.35 \pm 0.01 \mathrm{t}^{*}$ \\
\hline \multicolumn{6}{|c|}{ serum } \\
\hline AST, mmol/(h・l) & $1.67 \pm 0.08$ & $2.71 \pm 0.22^{*}$ & $2.30 \pm 0.06 * / * *$ & $2.10 \pm 0.09 * / * *$ & $2.19 \pm 0.12 * / * *$ \\
\hline \multicolumn{6}{|c|}{ homogenate of the heart } \\
\hline $\mathrm{RG}, \mu \mathrm{mol} / \mathrm{g}$ & $3.16 \pm 0.71$ & $1.40 \pm 0.21 *$ & $2.52 \pm 0.22$ & $2.80 \pm 0.22 \mathrm{t}^{* *}$ & $2.34 \pm 0.21 \mathrm{t} * *$ \\
\hline TBA, $\mu \mathrm{mol} / \mathrm{g}$ & $28.63 \pm 1.19$ & $51.79 \pm 3.70 *$ & $46.58 \pm 1.03 * / * * * / \#$ & $27.99 \pm 2.30 * *$ & $31.84 \pm 2.46^{* *}$ \\
\hline
\end{tabular}

Note: * -differences are significant compared to intact control, $p<0.05 ; * *$-differences are significant compared to the positive control, $p<0.05 ; * * *$-differences are significant compared to PHTE at a dose of $200 \mathrm{mg} / \mathrm{kg}, \mathrm{p}<0,05$; \# - differences are significant compared to CD "Tricardin", $p<0,05 ; t$ - the tendency to probable changes, $0.05<p<0.10$

The study of ECG parameters (Table 4) showed that animals from the PC group had a slight increase in heart rate $(\mathrm{p}>0.05)$ against IC, and statistically significant according to the IC group increase in SP $(64.07 \pm 1.92 \%$ vs. $42.84 \pm 1.92 \%, \mathrm{p}<0.05)$, as well as a decrease in the QRS interval $(0.013 \pm 0.001 \mathrm{~s}$ vs. $0.017 \pm 0.001 \mathrm{~s}, \mathrm{p}<0.05)$, an increase in the QT interval $(0.086 \pm 0.004 \mathrm{~s}$ vs. $0.063 \pm 0.002 \mathrm{~s}, \mathrm{p}<0.05)$ and significant changes in the marker of myocardial ischemia - ST segment $(0.050 \pm 0.003 \mathrm{~s}$ vs. $0.024 \pm 0.004 \mathrm{~s}, \mathrm{p}<0.05)$ were detected.

Such changes in ECG parameters do not correspond to the classical picture of the pacing effect of adrenaline but have a basis for explanation. It is known that at physiological (moderate) concentrations adrenaline acts on ventricular cardiomyocytes through the activation of $\beta_{2}$-adrenoceptors and has a positive inotropic (increased strength of heart rate) and chronotropic (increased heart rate) effect. This effect of adrenaline is realized through the activation of the cascade of reactions that are triggered during the conformation of Gs (stimulating) membrane protein. At high concentrations, adrenaline, namely those used in the experiment, is a traumatic agent, causing spasm of myocardial vessels, contributing to the development of ischemia, as evidenced by a significant displacement of the ST segment. It is known that in the affected myocardium significantly increases the density and activity of membrane Gi (inhibitory) protein compared to Gs (stimulating) protein. Against this background, the hormone-receptor complex Gs- $\beta_{2}-$ adrenoceptors-Gi blocks L-type calcium channels, leading to adverse heart reactions: decreased amplitude of the QRS complex, prolongation of the QT interval, indicating a decrease in myocardial excitability [28].

Thus, the established changes in the activity of the heart are a consequence of the cardiotoxic effects of adrenaline and the development of ischemia in PC rats.

Table 4

The effect of PHTE and the comparison drug "Tricardin" on the functional state of the myocardium in rats with a model of adrenaline myocardial infarction $(\mathrm{M} \pm \mathrm{m})$

\begin{tabular}{|c|c|c|c|c|c|}
\hline \multirow[b]{2}{*}{ Indicators } & \multicolumn{5}{|c|}{ Умови досліду } \\
\hline & $\begin{array}{l}\text { Intact con- } \\
\text { trol }(\mathrm{n}=6)\end{array}$ & $\begin{array}{c}\text { Positive control } \\
(\mathrm{n}=6)\end{array}$ & $\begin{array}{c}\text { PHTE, } 100 \mathrm{mg} / \mathrm{kg} \\
(\mathrm{n}=6)\end{array}$ & $\begin{array}{c}\text { PHTE, } 200 \mathrm{mg} / \mathrm{kg} \\
(\mathrm{n}=6)\end{array}$ & $\begin{array}{l}\text { Tricardin, } 5 \text { drops } / \mathrm{kg} \\
(\mathrm{n}=6)\end{array}$ \\
\hline $\mathrm{HR}, \mathrm{bts} / \mathrm{min}$ & $405.36 \pm 8.34$ & $448.35 \pm 8.08$ & $421.11 \pm 14.54$ & $415.61 \pm 12.36$ & $427.20 \pm 17.31$ \\
\hline $\mathrm{SP}, \%$ & $42.84 \pm 1.92$ & $64.07 \pm 1.92 *$ & $53.67 \pm 1.72 * / * *$ & $49.76 \pm 2.98 \mathrm{t} * / * *$ & $53.69 \pm 3.63 * / * *$ \\
\hline $\mathrm{QT}, \mathrm{c}$ & $0.063 \pm 0.002$ & $0.086 \pm 0.004 *$ & $0.077 \pm 0.002 * / * *$ & $0.072 \pm 0.003 * / * *$ & $0.075 \pm 0.002 * / * *$ \\
\hline $\mathrm{PQ}, \mathrm{c}$ & $0.046 \pm 0.002$ & $0.048 \pm 0.004$ & $0.047 \pm 0.003$ & $0.045 \pm 0.002$ & $0.047 \pm 0.002$ \\
\hline QRS, c & $0.017 \pm 0.001$ & $0.013 \pm 0.001 *$ & $0.015 \pm 0.001 t^{*}$ & $0.016 \pm 0.001 \mathrm{t}^{*}$ & $0.015 \pm 0.001$ \\
\hline $\mathrm{R}, \mathrm{mV}$ & $0.54 \pm 0.03$ & $0.67 \pm 0.02$ & $0.55 \pm 0.04 \mathrm{~T}^{* *}$ & $0.49 \pm 0.03 * *$ & $0.60 \pm 0.06$ \\
\hline $\mathrm{P}, \mathrm{mV}$ & $0.06 \pm 0.01$ & $0.11 \pm 0.01$ & $0.10 \pm 0.02$ & $0.08 \pm 0.02$ & $0.063 \pm 0.01$ \\
\hline $\mathrm{T}, \mathrm{mV}$ & $0.13 \pm 0.02$ & $0.20 \pm 0.03$ & $0.17 \pm 0.01$ & $0.14 \pm 0.02$ & $0.18 \pm 0.02$ \\
\hline Offset ST, s & $0.024 \pm 0.004$ & $0.050 \pm 0.003^{*}$ & $0.035 \pm 0.004^{* *}$ & $0.030 \pm 0.005^{* *}$ & $0.037 \pm 0.003^{* *}$ \\
\hline
\end{tabular}


Under the influence of PHTE at doses of 100 and $200 \mathrm{mg} / \mathrm{kg}$, some normalization of some ECG parameters compared to PC was observed: slight insignificant decrease in heart rate and significant decrease $(p<0.05)$ in QT interval, which characterizes ventricular systole $0.077 \pm 0.002 \mathrm{~s}$ and 0.072 , respectively. $\pm 0.003 \mathrm{~s}$ against $0.086 \pm 0.004 \mathrm{~s}$ in the PC group), which contributed to a significant decrease in the rate of SP (respectively $53.67 \pm 1.72 \%$ and $49.76 \pm 2.98 \%$ against $64.07 \pm 1.92 \%$ in the PC group) ), and the positive dynamics before the normalization of the tooth R. PHTE in both doses contributed to a decrease in the displacement of the ST segment (respectively $0.035 \pm 0.004 \mathrm{~s}$ (at a dose of $100 \mathrm{mg} /$ $\mathrm{kg}$ ) and $0.030 \pm 0.005$ (at a dose of $200 \mathrm{mg} / \mathrm{kg}$ ) against $0.050 \pm 0.003$ in the PC group), which indicates its ability to reduce the cardiotoxic effects of adrenaline and the severity of ischemia. The comparison drug "Tricardin" showed a similar effect to PHTE on the functional state of the myocardium in adrenaline intoxication.

Significant $(p<0.05)$ reduction of cardiac BM occurred against the background of PHTE at a dose of 200 $\mathrm{mg} / \mathrm{kg}$, which indicates a decrease in the severity of alternative processes in the body. Under the influence of PHTE at a dose of $100 \mathrm{mg} / \mathrm{kg}$ and the comparison drug, an increase in cardiac BM was observed compared with intact control at the trend level $(0.05<\mathrm{p}<0.1)$, which was almost at the PC level. The use of PHTE in both doses and the comparison drug "Tricardin" reduced the severity of cytolytic processes: the activity of the enzyme AST a marker of cardiocytolysis, was lower than in the PC group: respectively $2.30 \pm 0.06 \mathrm{mmol} /(\mathrm{h} \bullet \mathrm{l})$ under the influence of PHTE at a dose of $100 \mathrm{mg} / \mathrm{kg}$ and $2.10 \pm 0.09 /(\mathrm{h} \bullet 1)$ under the influence of PHTE at a dose of $200 \mathrm{mg} / \mathrm{kg}$ and $2.19 \pm 0.12$ under the influence of CD against $2.71 \pm 0.22 \mathrm{mmol} /(\mathrm{h} \bullet \mathrm{l})$ in the $\mathrm{PC}$ group.

A study of the effect of PHTE on the LPO/AOP system showed that the drug showed a more pronounced antioxidant effect at a dose of $200 \mathrm{mg} / \mathrm{kg}$ : there was a tendency to increase RG levels and a significant decrease in TBA in 1.85 times compared to the PC group. A similar effect was found in the comparison drug "Tricardin". PHTE at a dose of $100 \mathrm{mg} / \mathrm{kg}$ was less effective. It is obvious that the containment of disorders in the LPO/AOP system affected the functional state of the myocardium: under the influence of PHTE there is a tendency to decrease heart rate and a significant decrease in systolic index compared to the PC group.

\section{Discussion of research results}

It is known that adrenaline in high doses has an excessive stimulating effect on the myocardium, which leads to increased oxygen demand, hypoxia, ischemia, disorders of plastic and energy metabolism in the myocardium [3, 4]. Violations of lipid metabolism in the myocardium, increased lipotoxicity [5], which creates conditions for disruption in the LPO / AOP system [6, 7], as evidenced by increased TBA LPO and decreased levels of the antioxidant system RG in the myocardium of rats from PC.

Phenolic compounds of plants are known antioxidants and show cytoprotective activity [26, 27]. Our results allow us to assert the pronounced anticytolytic and antioxidant properties of PHTE, as evidenced by a decrease in the marker of cytolysis of AST and LPO/TBA products and an increase in RG concentration in rats with a model of adrenaline myocardial infarction. The anticytolytic and antioxidant properties of PHTE were more pronounced at a dose of $200 \mathrm{mg} / \mathrm{kg}$. The described dynamics of the studied parameters along with the normalization of heart rate and functional state of the heart proves the effectiveness of PHTE in catecholamineinduced heart disease, in particular those occurring under stress, as stress is accompanied by increased levels of catecholamine adrenaline $[1,2]$.

The comparison drug "Tricardin" had a similar effect to PHTE on cytolytic processes and the state of the LPO/AOC system in the myocardium. Biologically active substances contained in the roots and rhizomes of valerian (ester of borneol and isovaleric acid, borneol, isovaleric acid, alkaloids, tannins, sugars), reduce the excitability of the CNS, reduce stress and irritability in the psyche, hypnotic, antispasmodic properties. Biologically active substances contained in the herb nettle (essential oil) (essential oil, saponins, tannins, alkaloids), reduce the processes of excitation in the CNS, contribute to the normalization of blood pressure. Biologically active substances contained in hawthorn fruits (flavonoids, choline, acetylcholine, tannins, phytosterols) have antihypertensive, cardioprotective, antispasmodic properties; increase blood circulation in coronary vessels and cerebral vessels, increase the contraction of the heart muscle and at the same time reduce its excitability [16].

The established anticytolytic, antioxidant and cardioprotective properties of the obtained parsnip of sowing grass extract justify the relevance of its further study in order to create on its basis drugs of cardioprotective action.

Study limitations. Only LPO products were studied in the experiment, but the evaluation of protein oxidation products, which are also markers of cardiomocyte damage, is also relevant.

Prospects for further research. In the future it is planned to study the level of protein oxidation products as markers of cardiomocyte damage in catecholamine myocardial infarction

\section{Conclusions}

1. Pasternak grass seed extract is a thick extract under the conditions of therapeutic and prophylactic administration to rats with a model of adrenaline myocardial infarction exhibits antioxidant and anticytolytic activity, which improves myocardial function and reduces the severity of alternative processes in the body.

2 . The severity of the cardioprotective effect of PHTE at a dose of $200 \mathrm{mg} / \mathrm{kg}$ is not inferior to the comparison drug "Tricardin".

\section{Conflict of interests}

The authors declare that they have no conflicts of interest.

Financing

The study was performed without financial support. 


\section{References}

1. Boland, T. A., Lee, V. H., Bleck, T. P. (2015). Stress-Induced Cardiomyopathy. Critical Care Medicine, 43 (3), $686-693$. doi: http://doi.org/10.1097/ccm.0000000000000851

2. Wallner, M., Duran, J. M., Mohsin, S., Troupes, C. D., Vanhoutte, D., Borghetti, G. et. al. (2016). Acute Catecholamine Exposure Causes Reversible Myocyte Injury Without Cardiac Regeneration. Circulation Research, 119 (7), 865-879. doi: http://doi.org/10.1161/ circresaha.116.308687

3. Wang, A. R., Dean, S. A., Grebe, S. K., Hood, I. C. (2016). Fatal Catecholamine-Induced Cardiotoxicity Associated with Pheochromocytoma: Report of a Postpartum Case and Review of the Literature. Academic Forensic Pathology, 6 (2), 315-324. doi: http://doi.org/10.23907/2016.032

4. Khara, M. R., Shkumbatiuk, O. V., Kuchyrka, L. I. (2014). Kharakterystyka stupenia poshkodzhennia miokarda adrenalinom u shchuriv riznoi stati zalezhno vid tryvalosti sposterezhennia ta rivnia statevykh hormoniv. Visnyk morfolohii, 20 (2), 372-375.

5. Omerovic, E. (2011). How to think about stress-induced cardiomyopathy? - Think "out of the box"! Scandinavian Cardiovascular Journal, 45 (2), 67-71. doi: http://doi.org/10.3109/14017431.2011.565794

6. Kazymyrko, V. K., Yvanytskaia, L. N., Kutovoi, V. V., Dubkova, A. H., Sylanteva, T. S. (2014). Perekysne okysnennia lipidiv: protyrichchia problemy. Ukrainskyi revmatolohichnyi zhurnal, 57 (3), $13-17$.

7. Bezkorovaina, H. O., Klishch, I. M., Khara, M. R. (2020). Gender difference of free-radical processes in the myocardium at adrenaline damage on the background of light deprivation. Medical and Clinical Chemistry, 4, 13-19. doi: http://doi.org/10.11603/ mcch.2410-681x.2019.v.i4.10821

8. Sobhani, Z., Nami, S. R., Emami, S. A., Sahebkar, A., Javadi, B. (2017). Medicinal Plants Targeting Cardiovascular Diseases in View of Avicenna. Current Pharmaceutical Design, 23 (17), 2428-2443. doi: http://doi.org/10.2174/1381612823666170215104101

9. Zhabborova, D. M., Karomatov, I. D. (2018). Lekarstvennoe rastenie pasternak. Biologiia i integrativnaia meditsina, 22 (5), 115-120. Available at: https://cyberleninka.ru/article/n/lekarstvennoe-rastenie-pasternak

10. Shkhanukova, Z. Kh., Konovalov, D. A. (2015). Izuchenie mineralnogo sostava pasternaka posevnogo (Pastinaca sativa L.). Sovremennye problemy nauki i obrazovaniia, 2 (2). Available at: https://science-education.ru/ru/article/view?id=23037

11. ST-N MOZU Nastanova 42-4.0:2020 «Likarski zasoby. Nalezhna vyrobnycha praktyka» (2020). Kyiv: MOZ Ukrainy, 338. Available at: https://www.dls.gov.ua/wp-content/uploads/2020/05/Настанова-CT-Н-МО3У-42-4.0_2020.pdf

12. Kozhemiakin, Yu. M., Khromov, O. S., Filonenko, M. A., Saifetdynova H. A. (2002). Naukovo-praktychni rekomendatsii $\mathrm{z}$ utrymannia laboratornykh tvaryn ta roboty z nymy. Kyiv: Avitsena, 156.

13. Liapunova, N. A., Zagoriia, V. A., Georgievskogo, V. P., Bezugloi, E. P. (Eds.) (1999). Direktiva Soveta ES o sblizhenii zakonov, postanovlenii i administrirovanie polozhenii gosudarstv ES po voprosam zaschity zhivotnykh, ispolzuemykh dlia eksperimentalnykh i drugikh nauchnykh tselei (86/609/EES). Nadlezhaschaia proizvodstvennaia praktika lekarstvennykh sredstv. Kyiv: Morion, 508-545.

14. Stefanova, O. V. (Ed.) (2001). Doklinichni doslidzhennia likarskykh zasobiv. Kyiv: Avitsenna, 528.

15. ST-N MOZU Nastanova 42-6.0:2008. Likarski zasoby. Nalezhna laboratorna praktyka (2012). Vydannia ofitsiine. Kyiv: Ministerstvo okhorony zdorovia Ukrainy. Available at: https://compendium.com.ua/uk/clinical-guidelines-uk/standartizatsiyafarmatsevtichnoyi-produktsiyi-tom-2/st-n-mozu-42-6-0-2008/

16. Likarskyi zasib «Trykardyn sertsevi krapli». Derzhavnyi reiestr likarskykh zasobiv Ukrainy: Instruktsiia dlia medychnoho zastosuvannia. Available at: http://www.drlz.com.ua/ibp/ddsite.nsf/all/shlz1 ?opendocument\&stype=4C48CB109042CC90C225863F00431A1B

17. Fisenko, V. P. (Ed.) (2000). Rukovodstvo po eksperimentalnomu (doklinicheskomu) izucheniiu novykh farmakologicheskikh veschestv. Moscow: Remedium, 398.

18. Shymorova, Yu. Ye., Kyslychenko, V. S. (2020). Pat. No. 139957 UA. Protyzapalnyi zasib na osnovi pasternaku posivnoho. MPK: A61K 9/08 (2006.01), A61K 36/00, A61P 29/00. No. u 2019 10054. declareted: 27.09.2019; published: 27.01.2020, Bul. No. 2.

19. Shymorova, Yu. Ye. (2020). Pharmacognostic study of parsnip (Pastinaca sativa L.). Kharkiv, 173.

20. Derzhavna Farmakopeia Ukrainy: in 3 edition (2015). DP «Ukrainskyi naukovyi farmatsevtychnyi tsentr yakosti likarskykh zasobiv». 2nd ed. Kharkiv: Derzhavne pidpryiemstvo «Ukrainskyi naukovyi farmatsevtychnyi tsentr yakosti likarskykh zasobiv», 1, 1128.

21. Horiacha, L., Symonenko, N., Galuzinska, L., Shpychak, O., Kyslychenko, V. (2020). The study of the cardioprotective action of the thick extract of parsnip herb. Ukrainian Biopharmaceutical Journal, 4 (65), 46-50. doi: http://doi.org/10.24959/ubphj.20.294

22. Shchokina, K. H., Shtryhol, S. Yu., Bielik, H. V., Butko, Ya. O. (2010). Experimental examination of cardiotread activity of recombinant antagonist of receptors of interleukin-1 (ARYL-1) and lipin on the model of immobilization stress at rats. Ukrainskyi biofarmatsevtychnyi zhurnal, 2 (7), 39-43. Available at: http://nbuv.gov.ua/UJRN/ubfj_2010_2_9

23. Orekhovich, V. N. (Ed.) Sovremennye metody v biohimii (1977). Moscow: Medicina, 66-68.

24. Beutler, E., Duron, O., Kelly, B. M. (1963). Improved method for the determination of blood glutathion. Journal of Laboratory and Clinical Medicine, 61, 882-888.

25. Symonenko, N. A., Mishchenko, O. Ya., Shpychak, O. S., Grashchenkova, S. A., Berezniakov, A. V., Khalieieva, O. L. (2021). Cardioprotective properties of tablets with a thick extract of the herb pasternak in the conditions of adrenaline myocardiodystrophy. PharmacologyOnline, 3, 376-382. Available at: https://pharmacologyonline.silae.it/files/archives/2021/vol3/PhOL_2021_3_A041_Symonenko.pdf

26. Iermolenko, T. I., Chorna, N. S., Shapoval, O. M. (2019). The theoretical substantiation of the search for potential medicinal products containing biologically active substances from the food plant raw material. Clinical pharmacy, 23 (2), 30-38. doi: http://doi.org/10.24959/cphj.19.1490

27. Zaychenko, G., Mishchenko, O., Sharifov, Ch., Gordienko, A., Tkachova, O., Sinitsyna, O. et. al. (2019). Influence of extract of peach ordinary (persica vulgaris) leaves on the state of the hypothalamic-pituitary-adrenal system of rats in conditions of chronic immobilization stress. Problems of Endocrine Pathology, 68 (2), 89-97. doi: http://doi.org/10.21856/j-pep.2019.2.13

28. Putenkova, L. Yu., Narezkina, L. P., Osipov N. M. (2010). Vliyanie adrenalina na serce lyagushki v usloviyah termicheskogo nekroza miokarda. Vestnik medicinskoj akademii, 3, 112-114. 
Natalia Symonenko, Postgraduate Student, Department of Industrial Pharmacy and Economy, Institute for Advanced Training of Pharmacy Specialists, National University of Pharmacy, Pushkinska str., 53, Kharkiv, Ukraine, 61002

Oleh Shpychak*, Doctor of Pharmaceutical Sciences, Professor, Department of Industrial Pharmacy and Economy Institute for Advanced Training of Pharmacy Specialists, National University of Pharmacy, Pushkinska str., 53, Kharkiv, Ukraine, 61002

Oksana Mishchenko, Doctor of Pharmaceutical Sciences, Professor, Department of Clinical Pharmacology, Institute for Advanced Training of Pharmacy Specialists, National University of Pharmacy, Pushkinska str., 53, Kharkiv, Ukraine, 61002

Viktoriia Kyslychenko, Doctor of Pharmaceutical Sciences, Professor, Head of Department, Department of Chemistry of Natural Compounds and Nutritiology, National University of Pharmacy, Pushkinska str., 53, Kharkiv, Ukraine, 61002

Tamara Shpychak, PhD, Associate Professor, Department of Organic Chemistry, National University of Pharmacy, Pushkinska str., 53, Kharkiv, Ukraine, 61002

Svetlana Grashchenkova, Senior Laboratory Assistant, Department of Clinical Pharmacology, Institute for Advanced Training of Pharmacy Specialists

National University of Pharmacy, Pushkinska str., 53, Kharkiv, Ukraine, 61002

*Corresponding author: Oleh Shpychak, e-mail: shpychak.oleg@gmail.com 